\title{
ANALISA KONSUMSI ENERGI LISTRIK RUMAH DENGAN KENDALI OTOMATIS
}

\author{
Benriwati Maharmi ${ }^{1}$, Toriq Kardova ${ }^{2}$, Ermawati ${ }^{3}$ \\ Jurusan Teknik Elektro, Sekolah Tinggi Teknologi Pekanbaru (STTP) \\ Riau 28289, Indonesia \\ Email: benriwati@sttp-yds.ac.id
}

\begin{abstract}
ABSTRAK
Pengontrolan lampu rumah secara otomatis dapat menghemat konsumsi energi sehingga mengurangi biaya pembayaran listrik. Paper ini bertujuan membandingkan konsumsi energi listrik secara manual dengan kendali otomatis pada lampu penerangan rumah menggunakan mikrokontroler Arduino Mega 2560, karena memiliki kelebihan yaitu jumlah input/output yang banyak sehingga fleksibilitas beban lampu yang dikontrolpun bisa lebih banyak. Modul Relay berfungsi mengontrol On/Off secara otomatis. Permasalahan yang dialami jika menggunakan saklar kontak $O n / O f f$ manual adalah pada saat menghidupkan atau mematikan lampu tidak pada jam yang sama karena kelalaian manusia sehingga pemakaian daya tidak terkontrol dengan baik. Hasil pengujian yang telah dilakukan selama sebulan dengan beban maksimal 300 Watt diperoleh konsumsi daya listrik yang terbaca pada $\mathrm{kWh}$ meter dengan menggunakan alat kendali otomatis sebesar $61,4 \mathrm{kWh}$ sedangkan pada sistem manual sebesar $85,7 \mathrm{kWh}$. Sehingga di dapatkan selisih daya sebesar 24,3 kWh. Penghematan biaya listrik sebesar 35,655 (TDL; Rp 1.467,28/kWh), dengan demikian pemakaian alat kendali otomatis untuk mengontrol lampu penerangan rumah terbukti lebih hemat energi listrik dibandingkan dengan sistem manual menggunakan saklar On/Off.
\end{abstract}

Kata kunci : Konsumsi energi listrik, Arduino Mega

\begin{abstract}
An automatic control of the home lights can save energy consumption, thereby reducing the cost of electricity payment. This paper aims to test the Cost Saving Energy Electricity tool with automatic control of home lighting using Arduino Mega 2560 microcontroller, because it has advantages that the number of input / output a lot so that the flexibility of the controlled light load can be more. The control system used a RTC (Real Time Clock) method, which has excess timer that can always be up-to-date. Also, the ACS-712 Current Sensor can measure the outflow current on the light load to be displayed by LCD and the Relay Module can control automaticly On/Off. However, problems experienced when using the On/Off switch contact manually that was turn on or off the light, which at the different clocks due to human negligence so that the power consumption being not well controlled. Test results that have been done for a month with a maximum load of 300 Watt was obtained electric power consumption for reading on $\mathrm{kWh}$ meter by using cost saving energy tool of $61.4 \mathrm{kWh}$ while in the manual system of $85.7 \mathrm{kWh}$. Furthermore, it got the power difference of $24.3 \mathrm{kWh}$. The value of electricity cost savings of 35.655 (TDL, $R p ~ 1,467.28 / \mathrm{kWh}$ ). Therefore, the use of cost saving energy to control home lighting automatically proved more energy efficient than the manual system using the On/Off switch.
\end{abstract}

Keywords: Elctrical energy consumption, Arduino Mega 


\section{PENDAHULUAN}

Kebutuhan listrik yang besar tidak sebanding dengan ketersediaan energi listrik yang ada saat ini. Pemerintah juga merancang program strategis nasional yaitu pembangunan pembangkit listrik sebesar 35.000 MW untuk memenuhi kebutuhan energi listrik nasional dan dalam Peraturan Presiden RI No.5 tahun 2016 tentang kebijakan energi nasional [1] serta penelitian tentang energi baru dan terbarukan juga telah banyak dilakukan untuk mengantikan pembangkit listrik berbahan batu bara dan gas bumi yang merupakan sumber energi yang tidak dapat diperbaharui, sehingga penting untuk melakukan hemat energi listrik. Penghematan energi listrik selain bisa mengurangi pengeluaran keuangan ternyata juga bersifat sosial, yaitu membantu mengurangi resiko pemanasan global [2]. Konservasi energi listrik untuk penggunaan energi yang lebih efisien akan mengurangi konsumsi energi listrik sehingga dengan adanya konservasi energi listrik akan berdampak kepada berkurangnya biaya listrik yang terpakai.

Faktor kesibukan dan kelalaian dari konsumen listrik yang banyak pergi bekerja meninggalkan rumah dari pagi dan terkadang pulang larut malam sehingga penerangan rumah yang ditempatkan diteras atau halaman, ruang tamu, kamar tidur, kamar mandi, dapur, garasi atau gudang dan penerangan lainnya di rumah yang sering terlambat mematikan di pagi hari karena faktor kesibukan atau bahkan sampai lupa untuk mematikan sehingga lampu hidup seharian, akibatnya pemakaian daya listrik setiap bulannya semakin tinggi dan biaya listrik yang harus dikeluarkan karena pemakaian yang tidak efisien ini mahal, padahal pemilik rumah jarang berada dirumah pada saat hari efektif karena faktor pekerjaan. Hal ini tentu saja akan memberatkan konsumen listrik ditambah dengan kenaikan tarif daya listrik per kWh nya semakin naik.

Perkembangan teknologi elektronika yang sangat pesat, banyak muncul ide-ide kreatif untuk mengontrol penggunaan energi listrik dirumah tangga dengan berbagai istilah seperti smart home, green building, intelligent Building dan lain sebagainya [3]. Sistem Pengontrolan otomatis ini akan mempermudah pekerjaan setiap orang dalam mematikan dan menyalakan lampu secara cepat, tepat, kreatif, dan efisien dengan menggunakan mikrokontroler [2]. Seiring dengan perkembangan tersebut, menghadirkan beberapa teknologi yang mampu diterapkan dalam kehidupan masyarakat luas untuk membantu dalam setiap aktifitas manusia. Salah satu sistemnya yaitu mampu memonitoring dan mengontrol penggunaan energi listrik.
Shalat [4] melakukan penelitian dengan mengontrol penerangan Lampu rumah secara otomatis menggunakan kontrol PLC Omron dan Timer yang terdapat pada internal PLC. Kontrol menggunakan PLC selain harganya yang relatif mahal juga kurang efisien jika hanya digunakan sebagai pengontrol lampu saja. Disamping itu, sistem kontrol internal timer menggunakan PLC sangat dipengaruhi oleh kontinuitas power supply, jika PLC mati karena power supply PLN mengalami pemadaman, maka timer tersebut akan tereset ke waktu awal, sehingga pengontrolan internal timer pada PLC kurang akurat.

Selanjutnya, Wiyatno [5] melakukan penelitian dengan membuat alat pengontrol peralatan rumah tangga secara otomatis menggunakan timer digital dan mikrokontroler Atmel 89S52. Alat ini hanya bisa mengontrol otomatisasi On/Off peralatan rumah tangga, dan tidak dapat memonitor besarnya arus pada beban peralatan rumah tangga tersebut. Suryono [6] mengontrol lampu jarak jauh menggunakan android pengendali dengan memanfaatkan sinyal bloetooth. Juga penelitian yang dilakukan oleh Ramlee dan Leong [7] dengan tujuan membantu penghuni rumah yang menyandang cacat dan manula untuk mempermudah mematikan lampu dari jarak jauh. Pengontrolan dengan menggunakan sinyal bloetooth ini mempunyai kelemahan dimana batas jarak maksimal 7-8 meter, lebih dari 9-10 meter penerimaan sinya lsudah kurang baik serta ditambah dengan kondisi terhalang maka sinyal tidak direspon lagi [6].

Roisin et al [8] menyatakan bahwa kontrol energi listrik juga bergantung pada orientasi ruangan dan lokasi. Mereka melakukan penelitian dengan membandingkan potensi penghematan energi pencahayaan di ruang kantor dengan menggunakan sistem kontrol yang berbeda berdasarkan simulasi. Studi menunjukkan bahwa penghematan pencahayaan listrik tinggi saat mengatur cahaya sesuai dengan ketersediaan siang hari. Bila sensor pemakaian daya listrik digunakan, penghematan energi listrik meningkat saat tingkat pemakaian menurun, namun hubungan antara tingkat pekerjaan dan konsumsi energi tidak linier seperti waktu tunda (waktu sebelum dimatikan atau dimming setelah pemakai meninggalkan ruangan) memiliki pengaruh yang lebih besar sebagai tingkat konsumsi energi listrik menurun.

Berdasarkan penelitian yang sudah dilakukan sebelumnya, maka penelitian ini bertujuan membandingkan konsumsi energi listrik menggunakan on/off manual dengan kendali on/off otomatis lampu penerangan rumah dengan kondisi beban yang bervariasi. Sistem on/off otomatis ini menggunakan RTC (Real Time Clock) untuk mengatur waktu dan sensor arus ACS712 yang berguna untuk membatasi 
penggunaan arus pada lampu penerangan rumah, sehingga sistem otomatisnya mampu menyalakan dan mematikan lampu penerangan rumah secara otomatis dengan waktu yang telah ditentukan, sehingga memberi dampak hemat biaya energi listrik.

\section{METODA PENELITIAN}

Pengujian dan pengambilan data alat kendali otomatis lampu rumah tangga yang dilakukan selama satu bulan untuk mengetahui apakah alat untuk pengontrol lampu secara otomatis ini sesuai dengan yang diharapkan dan kemudian membuat analisa dari pengujian hasil tersebut. Pengujian juga dilakukan dengan menggunakan beban yang bervariasi dengan menggunakan RTC (Real Time Clock) untuk mengatur berbagai timing untuk menampilkan jam selama periode tertentu. Pada Penelitian ini dilakukan pengontrolan lampu penerangan rumah yang terdiri dari 5 buah lampu dengan daya masing-masing 60 Watt sebagai beban. Alat ini menggunakan 4 input.

Saklar on/off manual ini juga bisa digunakan jika ingin menghidupkan atau mematikan lampu diluar setingan kontrol yang sudah dibuat misalnya dalam keadaan darurat yang memerlukan salah satu atau lebih lampu harus dihidupkan pada malam hari atau dalam keadaan-keadaan khusus. Selanjutnya, alat kontrol otomatis menggunakan relay modul berfungsi mengontrol on/ off lampu dengan sistem NO (Normally Open) dan NC (Normally Close) yang ada pada relay. Setingan waktu dan arus dilakukan pada keypad dan bisa dimonitor pada LCD untuk memudahkan penyetingan. Untuk pengontrolan otomatis ini sistem menggunakan mikrokontroler sebagai alat kontrol. Pada gambar 1 disajikan koneksi modul relay untuk on/off otomatis dengan beban lampu rumah.

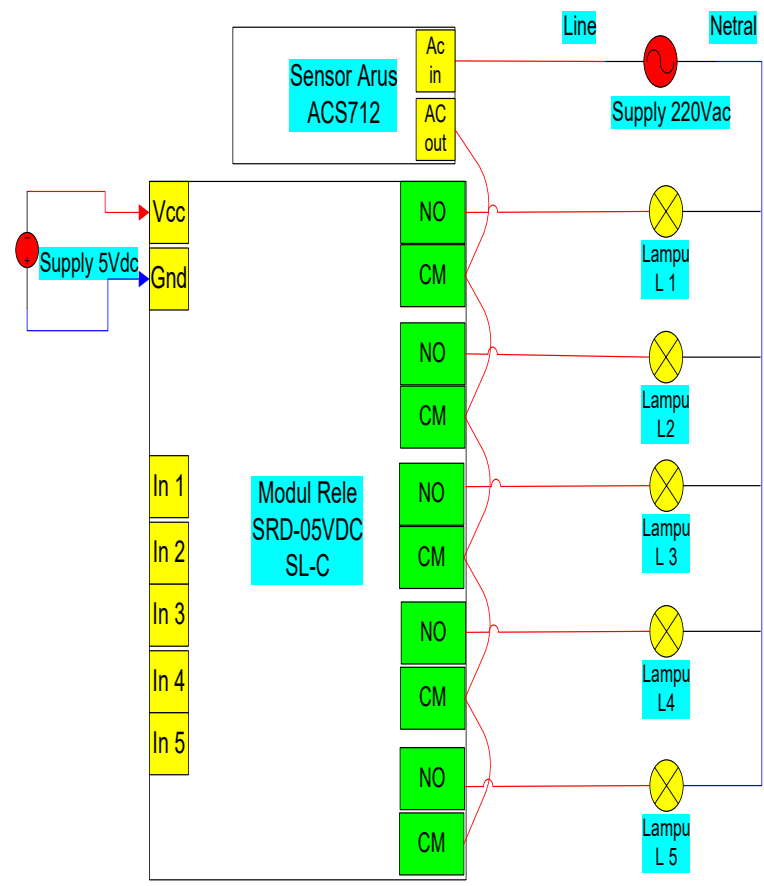

Gambar 1. Koneksi Modul Relay untuk On/Off Otomatis dengan Beban Lampu 5 x 60 watt

Pada gambar 2 menunjukkan Koneksi LCD (Liquid Crystal Display) dengan mikrokontroler Arduino Mega 2560

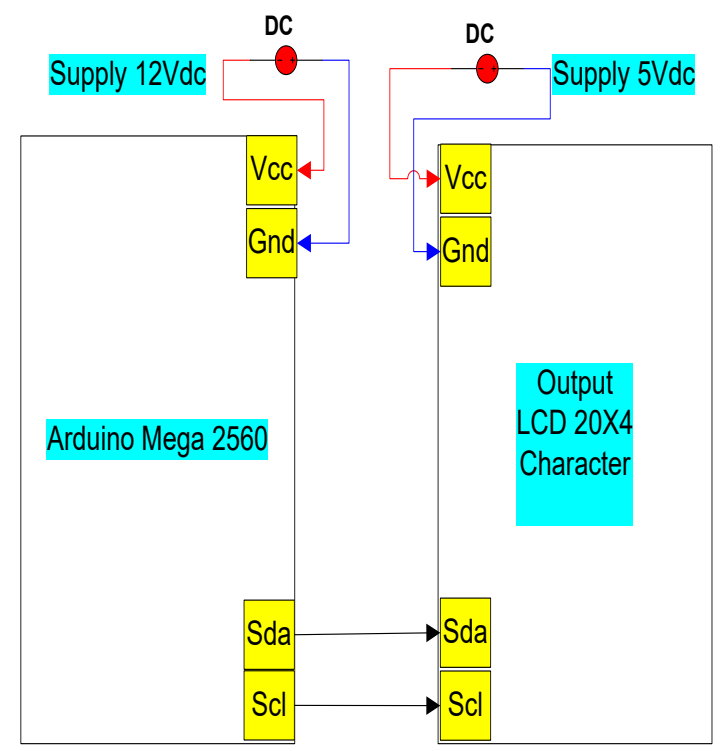

Gambar 2 menunjukkan Koneksi LCD (Liquid Crystal Display) dengan mikrokontroler Arduino Mega 2560 
Pada Gambar 3 adalah koneksi saklar on/ off dengan beban lampu rumah secara manual.

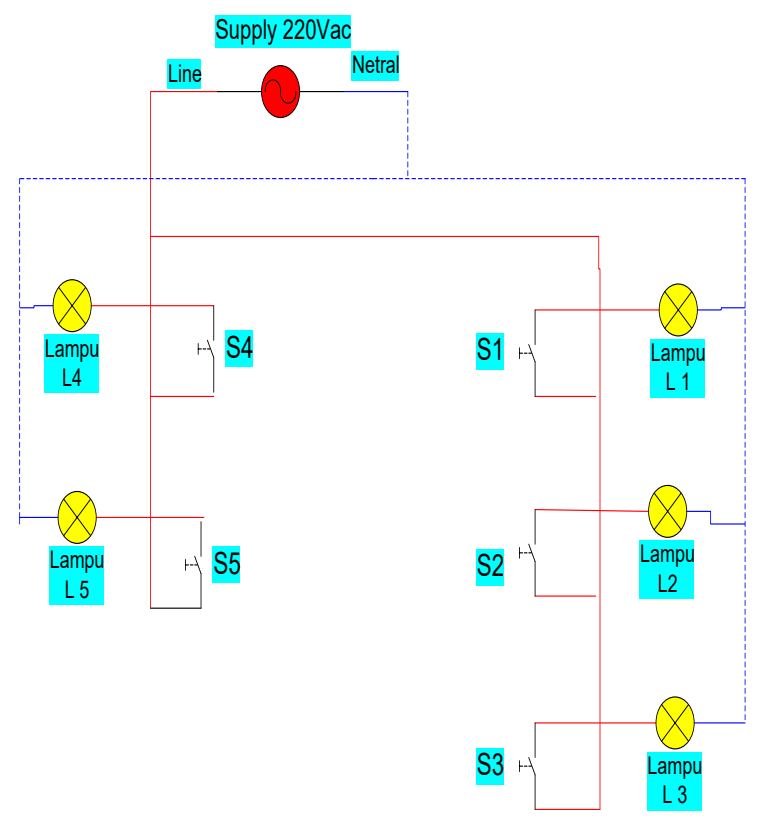

Gambar 3 Koneksi Saklar On/ Off Manual dengan Beban Lampu Rumah

Dari gambar 1 dapat dijelaskan cara kerja sistem sebagai berikut: sensor arus pada sistem menggunakan sensor arus ACS712 dengan kapasitas arus maksimal 5 ampere, sensor arus ini digunakan untuk membaca arus yang mengalir pada beban lampu rumah. Lalu dipadukan dengan Real Time Clock (RTC), untuk mengatur berapa besar arus maksimal yang dapat digunakan konsumen pada jam tertentu. Misalnya diseting waktu pada jam 18.00 sampai jam 21.00 arus yang dapat digunakan adalah 1,4 Ampere atau cukup untuk menyalakan semua lampu, lalu pada jam 21.00 sampai jam 05.00 arus yang dapat digunakan adalah 0,5 ampere. Untuk mengatur pengaturan tersebut digunakan keypad matrix dan juga display LCD untuk melihat tampilan waktu dan arus. Sedangkan untuk mengatur nyala dan matinya lampu secara otomatis digunakan rangkaian relay yang dihubungkan dengan beban lampu rumah. Alat ini juga dilengkapi dengan 5 buah Saklar On/ Off untuk mengoperasikan lampu secara manual. Power supply pada sistem ini digunakan untuk mensuplai daya semua komponen yang ada.

Pengambilan data beban lampu rumah juga dilakukan dengan menggunakan saklar on/off secara manual dengan menggunakan beban yang sama. Dimana saklar on/off-nya yang mengoperasikan adalah manusianya sendiri/ konsumen sendiri yang durasi waktunya diusahakan sesuai dengan jadwal yang disetting secara otomatis selama 30 hari. Data konsumsi energi dengan menggunakan on/off manual ini tidak bisa terlepas dari human error dan kesibukan konsumen dalam kegiatan sehari-harinya.

\section{HASIL DAN PEMBAHASAN}

Pada penelitian ini yang pertama dilakukan adalah pengujian pengukuran arus menggunakan sensor arus pada alat kendali otomatis dengan mengambil data pembacaan arus aktual menggunakan clamp Ampere Sanfix BM 256 dengan range tang Ampere 20 A dan tegangan input AC sumber dari PLN. Sistem di energize dalam kondisi beban lampu belum terpasang dan pembacaan arus aktual pada display LCD (sensing sensor Arus) terbaca 0,15 A sementara pada clamp ampere terbaca 0,0 A. Perbedaan pembacaan Sensor Arus ACS 712 dengan clamp ampere masih dalam batas toleransi yaitu $\pm 0,2$ A. Kemudian sistem dibebani dengan beban yang bervariasi, data pengujian dapat dilihat pada Tabel 1 .

Tabel 1. Pengukuran Arus

\begin{tabular}{ccc}
\hline $\begin{array}{c}\text { Beban } \\
\text { (watt) }\end{array}$ & $\begin{array}{c}\text { LCD } \\
\text { (A) }\end{array}$ & $\begin{array}{c}\text { Clamp Ampere } \\
\text { (A) }\end{array}$ \\
\hline $\mathbf{0}$ & 0,15 & 0,0 \\
$\mathbf{6 0}$ & 0,29 & 0,22 \\
$\mathbf{1 2 0}$ & 0,51 & 0,47 \\
$\mathbf{1 8 0}$ & 0,75 & 0,71 \\
$\mathbf{2 4 0}$ & 0,97 & 0,94 \\
\hline
\end{tabular}

Dari hasil Pengujian pembacaaan arus yang diberi beban menggunakan sensor arus ACS 712 pada alat kendali otomatis dengan clamp ampere diperoleh perbedaan rata-rata sebesar 0,05 Ampere. Perbedaan pembacaan arus ini masih dalam toleransi yang dibolehkan yaitu \pm 0,2 Ampere.

\subsection{Real Time Clock}

Pengujian RTC untuk on/off lampu secara otomatis dilakukan dengan menseting jam dan arus maksimal dimana input data jam awal 19.00 wib dan jam akhir 23.00 wib dengan seting arus 0,0 A. Input jam awal 11.00 wib dan jam akhir 20.00 wib dengan seting arus 1,4 A. Pada setingan ini ketika beban lampu menyala semua arus aktual terukur adalah 1,2 A. 
SainETIn (Jurnal Sain, Energi, Teknologi \& Industri), Vol. 2 No. 2, Juni 2018, pp. 37 - 43

ISSN 2548-6888 print, ISSN 2548-9445 online

Pada penelitian ini pengujian yang dilakukan pada RTC secara otomatis sudah sesuai dengan settingan jam dan arus.

\subsection{Pemakaian Daya pada Kwh Meter}

Pada penelitian ini pengujian dilakukan dengan cara membandingkan lampu yang on/off secara otomatis menggunakan alat kendali tomatis dengan on/off secara manual dengan melihat hasil pembacaan Kwh Meter. Pengukuran pemakaian penerangan rumah secara menual dilakukan dengan menghidupkan dan mematikan lampu pada sore hari dan mematikan lampu yang tidak digunakan pada malam hari serta mematikan semua penerangan rumah pada pagi harinya setelah bangun tidur, sedangkan secara otomatis menggunakan alat alat kendali dengan cara mensetting alat pada jam tertentu yaitu:

1. Data setingan jam 20.00-22.00 WIB dengan setingan arus maksimal 1,4 A (5 lampu menyala)

2. Data setingan jam 22.00-24.00 WIB dengan setingan arus maksimal 0,6 A (3 lampu menyala)

3. Data setingan jam 24.00-08.00 WIB dengan setingan arus maksimal $0,0 \mathrm{~A}$ (semua lampu mati)

Pengukuran konsumsi daya menggunakan alat kendali otomatis dan secara manual dapat dilihat pada Tabel 2.

Tabel 2. Pengukuran Konsumsi Daya Alat Kendali Otomatis Dan Secara Manual.

\begin{tabular}{ccc}
\hline Hari & $\begin{array}{c}\text { On/Off Otomatis } \\
(\mathbf{k W h})\end{array}$ & $\begin{array}{c}\text { On/Off Manual } \\
\text { (kWh) }\end{array}$ \\
\hline $\mathbf{0}$ & 0,9 & 0,9 \\
$\mathbf{1}$ & 3 & 3 \\
$\mathbf{2}$ & 5,2 & 5,8 \\
$\mathbf{3}$ & 7,3 & 8,2 \\
$\mathbf{4}$ & 9,4 & 10,3 \\
\hline
\end{tabular}

\begin{tabular}{ccc}
\hline $\mathbf{5}$ & 11,4 & 12,8 \\
$\mathbf{6}$ & 13,4 & 15,1 \\
$\mathbf{7}$ & 15,4 & 17,4 \\
$\mathbf{8}$ & 17,4 & 22,6 \\
$\mathbf{9}$ & 19,4 & 24,8 \\
$\mathbf{1 0}$ & 21,4 & 31,5 \\
$\mathbf{1 1}$ & 23,4 & 35,8 \\
$\mathbf{1 2}$ & 25,4 & 38,3 \\
$\mathbf{1 3}$ & 27,4 & 41,3 \\
$\mathbf{1 4}$ & 29,4 & 43,8 \\
$\mathbf{1 5}$ & 31,4 & 47,8 \\
$\mathbf{1 6}$ & 33,4 & 50,8 \\
$\mathbf{1 7}$ & 35,4 & 53,2 \\
$\mathbf{1 8}$ & 37,4 & 55,8 \\
$\mathbf{1 9}$ & 39,4 & 59,9 \\
$\mathbf{2 0}$ & 42,4 & 63,6 \\
$\mathbf{2 1}$ & 43,4 & 65,5 \\
$\mathbf{2 2}$ & 45,4 & 67,5 \\
$\mathbf{2 3}$ & 47,4 & 69,8 \\
$\mathbf{2 4}$ & 49,4 & 71,9 \\
$\mathbf{2 5}$ & 51,4 & 74,5 \\
$\mathbf{2 6}$ & 53,4 & 76,4 \\
$\mathbf{2 7}$ & 55,4 & 76,5 \\
$\mathbf{2 8}$ & 57,4 & 79,1 \\
$\mathbf{2 9}$ & 59,4 & 82,6 \\
$\mathbf{3 0}$ & 61,4 & 85,7 \\
\hline & &
\end{tabular}

Hasil perbandingan Konsumsi Daya Listrik Perhari dari Tabel 2 bisa dilihat pada grafik Gambar 4. 


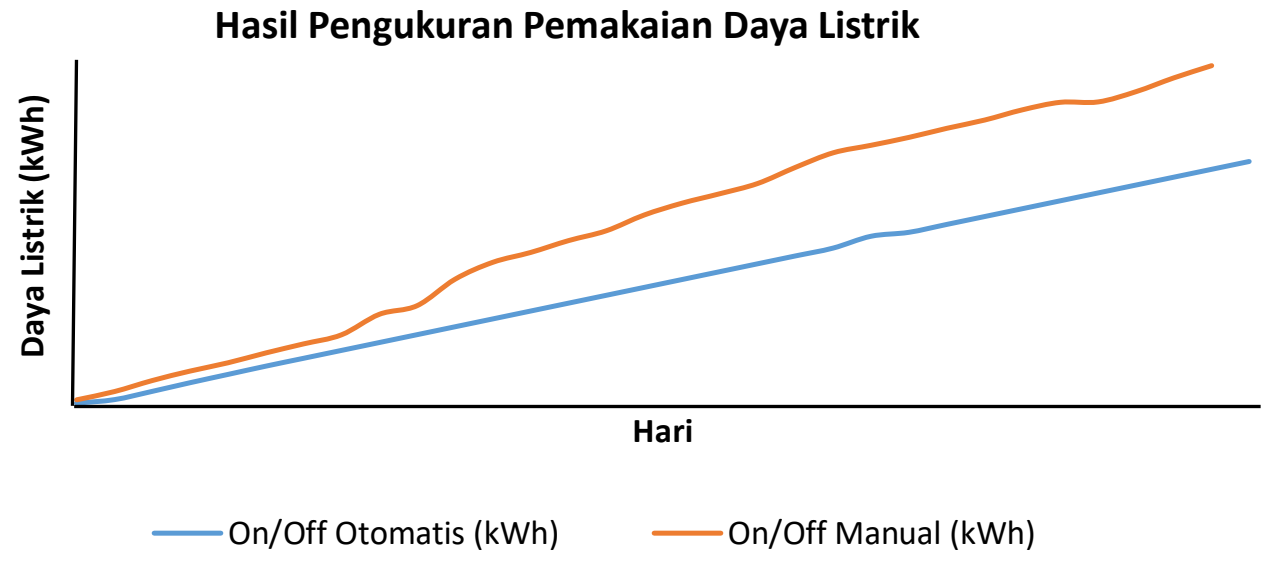

Gambar 4 Grafik Perbandingan Konsumsi Daya Listrik Perhari

Pada Gambar 4 dapat dilihat konsumsi daya listrik memakai alat on/off manual diperoleh besar daya yang terukur pada $\mathrm{kWh}$ meter selama tiga puluh hari/satu bulan pemakaian listrik sebesar $85,7 \mathrm{kWh}$, lebih besar dibandingkan memakai alat kendali otomatis yang dibuat dalam penelitian ini yaitu sebesar $61,4 \mathrm{kWh}$. Pemakaian daya listrik menggunakan On/off secara manual lebih besar pemakaian dayanya akibat ketidaktepatan waktu dalam meng-on/off kan saklar. Dari hasil penelitian selama satu bulan kecenderungan komsumsi daya lisrik memakai on/off otomatis, penggunaan listrik lebih kecil dan linier karena timing dapat diatur oleh pengguna sesuai kebutuhan. Seperti lampu terang hanya selama periode tertentu lampu dimatikan setiap hari pada waktu yang telah ditentukan sebelumnya dan nonaktif pada waktu yang ditentukan sebelumnya secara otomatis sehingga menghemat banyak daya listrik. Dengan penghematan konsumsi daya listrik ini akan bermanfaat mengurangi biaya pembayaran listrik.

Biaya yang harus dikeluarkan oleh konsumen untuk konsumsi penggunaan listrik yang dilakukan selama tiga puluh hari/satu bulan menggunakan on/off secara manual tarif dasar listrik (TDL) Rp. 1.467,28/kWh [9] dengan yaitu:

$$
\begin{aligned}
& \text { Biaya listrik }=\text { Pemakaian }(\mathrm{kWh}) \times \text { Tarif Dasar } \\
& \text { Listrik [10] } \\
& =85,7 \mathrm{kWh} \times \mathrm{Rp} 1.467,28 / \mathrm{kWh} \\
& =\operatorname{Rp~125.745,9,-}
\end{aligned}
$$

Biaya pemakaian listrik menggunakan on/off secara otomatis yaitu:

42

https://journal.unilak.ac.id/index.php/SainETIn/index

$$
\begin{aligned}
& \text { Biaya listrik }=\text { Pemakaian }(\mathrm{kWh}) \times \text { Tarif Dasar } \\
& \text { Listrik } \\
& =61,4 \mathrm{kWh} \times \mathrm{Rp} 1.467,28 / \mathrm{kWh} \\
& =\text { Rp. 90.090, 9,- }
\end{aligned}
$$

Selisih biaya antara pemakaian listrik menggunakan on/off secara manual dan on/off secara otomatis diperoleh Rp. 125.745,9 - Rp. $90.090,9=$ Rp. 35.655. Pemakaian listrik yang harus dibayar oleh konsumen untuk pemakaian listrik selama satu bulan menggunakan alat cost saving energy lebih hemat sebesar Rp. 35.655,dengan beban simulasi maksimal sebesar 300 Watt.

\section{KESIMPULAN}

1. Pada penelitian ini, sensor arus akan bekerja dengan lebih akurat jika arus total yang mengalir pada beban lampu lebih dari 0,1 Amp, karena sensor arus sendiri memiliki toleransi pembacaan arus $\pm 0,2 \mathrm{Amp}$.

2. Berdasarkan hasil pengujian, disimpulkan bahwa alat cost saving energy sudah bekerja sesuai yang diharapkan yaitu alat bisa mengontrol lampu On/Off secara otomatis, timer RTC dan sensor arus bisa bekerja dengan semestinya untuk membatasi arus sehingga dalam pemakaiannya dapat menghemat biaya energi listrik.

3. Hasil pengujian yang telah dilakukan selama sebulan dengan beban maksimal 300 Watt diperoleh konsumsi daya listrik yang terbaca pada $\mathrm{kWh}$ meter dengan menggunakan alat

\footnotetext{
Journal homepage:
} 
cost saving energy sebesar $61,4 \mathrm{kWh}$ sedangkan pada sistem manual sebesar 85,7 $\mathrm{kWh}$. Sehingga di dapatkan selisih daya sebesar 24,3 kWh. Penghematan biaya listrik sebesar 35,655 (TDL; Rp 1.467,28/kWh), dengan demikian pemakaian alat cost saving energy untuk mengontrol lampu penerangan rumah secara otomatis terbukti lebih hemat energi listrik dibandingkan dengan sistem manual menggunakan saklar On/Off.

\section{DAFTAR PUSTAKA}

[1] Peraturan Presiden Republik Indonesia nomor 5 Tahun 2006 Tentang Kebijakan Energi Nasional.

[2] N. Almali, K.S. Bahir and O. Atan, Ardunio based smart home automation system, Int. J. of Sci. Res. in Inf. Sys. and Eng. , vol. 2 (2), pp 1-5, Aug. 2016.

[3] Bahri. S, Sudrajat. A, Bangun Prototype Sistem Kontrol Jarak Jauh Berbasis Android, Simposium Nasional ateknologi Terapan (SNTT) 32015.

[4] I. W. Shalat, Simulasi pengaturan sistem penerangan secara otomatis dengan plc omron cpmla 20cdr A-V1, pp 1-9, 2015. [Online]. Available: http://jom.unpak.ac.id/.
[5] J. T. Wiyatno, Timer Digital Pengendali On/Off Peralatan Rumah Tangga Menggunakan Mikrokontroler Atmel 89S52, Jurnal Telkomnika Volume 3, No. 1 April 2015.

[6] Suryono, supriyati, Rancang Bangun Pengontrol Lampu Listrik menggunakan android dilengkapi dengan saklar manual, Jurnal Orbit Vol 13 No.2 Juli 2017, Hal. 7581.

[7] Ramlee, leong, Bluetooth Remote Home Automation System Using Android Application, The International Journal of Engineering And Science (IJES), Volume 2, No. 01, 2013, Hal. 149-153.

[8] Roisin B., M. Bodart, A. Deneyer, P. D'Herdt, Lighting energy savings in offices using different control systems and their real consumption, International Journal of Energy and Buildings, Volume 40, 2008, Hal. 514523.

[9] PLN, 2017, Tarif Dasar Listrik PLN, didapat dari : http://listrik.org/pln/tarif-dasar-listrik$\mathrm{pln} /$

[10] Watkins, A.J, Parton, Rk, 2004, Perhitungan Instalasi Listrik Volume I, Erlangga, Jakarta 